University of Nebraska - Lincoln

DigitalCommons@University of Nebraska - Lincoln

\title{
Equilibrium Sampling Used to Monitor Malodors in a Swine Waste Lagoon
}

Rezaul Mahmood

University of Nebraska - Lincoln

Follow this and additional works at: https://digitalcommons.unl.edu/natrespapers

Part of the Natural Resources and Conservation Commons, Natural Resources Management and Policy Commons, and the Other Environmental Sciences Commons

Mahmood, Rezaul, "Equilibrium Sampling Used to Monitor Malodors in a Swine Waste Lagoon" (2008). Papers in Natural Resources. 1269.

https://digitalcommons.unl.edu/natrespapers/1269

This Article is brought to you for free and open access by the Natural Resources, School of at DigitalCommons@University of Nebraska - Lincoln. It has been accepted for inclusion in Papers in Natural Resources by an authorized administrator of DigitalCommons@University of Nebraska - Lincoln. 


\section{Equilibrium Sampling Used to Monitor Malodors in a Swine Waste Lagoon}

\author{
John H. Loughrin* and Nanh Lovanh USDA-ARS \\ Rezaul Mahmood Western Kentucky University
}

The concentrations of malodorous compounds in a 0.4-ha anaerobic lagoon that received waste from approximately 2000 sows were monitored during the late summer to late fall of 2006 to gain insight into the factors influencing their concentrations. Selected malodorous compounds were measured by the use of equilibrium samplers consisting of submersible stir plates and stir bar sorbtive sampling with polydimethylsiloxanecoated magnetic stir bars. During the same period, air and water temperatures, suspended solids, total organic carbon and nitrogen content, and wastewater $\mathrm{pH}$ were recorded. Concentrations of malodorous compounds were higher at the surface of the lagoon than at the middle or bottom of the lagoon. Skatole concentration, for instance, averaged 54, 24 , and $38 \mu \mathrm{g} \mathrm{L}^{-1}$ near the surface, in the middle, and at the lowest sampling depths, respectively. While the lagoon was being pumped down during field application of wastewater, concentrations of malodorous compounds fluctuated widely, increased 16-fold as compared with the sampling period before pumping, and continued to increase as fall progressed and temperatures cooled. Suspended solids, volatile suspended solids, and total organic carbon increased near the bottom of the lagoon during this same period. The increases in the concentrations of malodorous compounds in the wastewater during the fall could have been due to a combination of several factors. These factors include reduced degradation by lagoon bacteria, less wind stripping of volatile compounds from the lagoon surface due to lowering of the lagoon surface after crop application, and/or reduced evaporation of malodorous compounds due to falling temperatures.

Copyright $\odot 2008$ by the American Society of Agronomy, Crop Science Society of America, and Soil Science Society of America. All rights reserved. No part of this periodical may be reproduced or transmitted in any form or by any means, electronic or mechanical, including photocopying, recording, or any information storage and retrieval system, without permission in writing from the publisher.

Published in J. Environ. Qual. 37:1-6 (2008).

doi:10.2134/jeq2006.0534

Received 13 Dec. 2006.

*Corresponding author (jloughrin@ars.usda.gov).

(1) ASA, CSSA, SSSA

677 S. Segoe Rd., Madison, WI 53711 USA
$A$ s THE number of animals raised in concentrated animal feeding Aoperations (CAFOs) increases, concerns over potentially adverse environmental impacts from these operations grow. Although there are many important issues that drive these concerns, the emission of malodorous compounds is the foremost factor driving public awareness of this matter. Malodorous compounds are produced from fresh feces and from waste-containment structures. Although the volatile compounds emitted from CAFOs are diverse (Schiffman et al., 2001), a limited number of these may be responsible for malodor (Williams, 1984; Hobbs et al., 1995; Zahn et al., 2001).

Among these, some of the most offensive- $p$-cresol, indole, skatole, and $p$-ethylphenol — are products of the anaerobic metabolism of aromatic amino acids and p-coumaric acid (Elsden et al., 1976; Spoelstra, 1977; van Beek and Priest, 2000). They are often cited as being major contributors to malodors in CAFOs (Spoelstra, 1977; Williams, 1984; Hobbs et al., 1995; Gralapp et al., 2001; Schiffman et al., 2001). In addition to having characteristically fecal odors, they also have low thresholds for olfactory detection. For instance, Schiffman et al. (2001) determined the odor thresholds of skatole and indole at $3.09 \mu \mathrm{g} \mathrm{m}^{-3}$ and $1.55 \times 10^{-2} \mathrm{\mu g} \mathrm{m}^{-3}$ air, respectively. However, inside a recently cleaned swine house, although they found offensive fecal odors, they found concentrations of skatole and indole of only $0.6 \mathrm{\mu g} \mathrm{m}^{-3}$ and $0.5 \mu \mathrm{g} \mathrm{m}^{-3}$, respectively. Although the concentration of skatole may have been below its odor threshold, they conjectured that swine housing odor offensiveness was due to the cumulative effects of numerous compounds, many of which were present below their individual odor threshold.

Although there is disagreement as to which compounds or combinations thereof are primarily responsible for malodors from CAFOs (Spoelstra, 1980; Williams, 1984; Mackie et al., 1998; Zhu et al., 1999; Schiffman et al., 2001; Zahn et al., 2001; McGinn et al., 2003), it may be important only to monitor the concentrations of a few key contributors to reliably assess the meteorological factors and/or management practices that affect the release of malodors from CAFOs. The aromatic compounds are ideal for this purpose: They are relatively stable compounds (Spoelstra, 1980) without ionizable functional groups and therefore seem likely to persist in the air long enough to facilitate accurate measurements and do not react with other species, such as ammonium or sulfate ions.

J.H. Loughrin and N. Lovanh, USDA-ARS, Animal Waste Management Research Unit 230 Bennett Ln., Bowling Green KY, 42104. R. Mahmood, Dep. of Geography and Geology, Western Kentucky Univ., Bowling Green, KY 42101.

Abbreviations: CAFO, concentrated animal feeding operations; MTBE, methyl tertbutyl ether; SBSE, stir bar sorbtive extraction; SPME, solid-phase microextraction; TOC, total organic carbon; VFA, volatile fatty acids. 
When conducting measurements of malodorous compounds from CAFOs, it is desirable to obtain concomitant measurement of the concentrations of malodors from their source. In this way, source concentrations of volatiles may be factored in when investigating the factors that influence concentrations and fluxes of malodors from CAFOs. Solid-phase microextraction (SPME) is a common technique for the measurement of malodors in wastewater (Buchholz and Pawliszyn, 1994; Zahn et al., 1997; Loughrin, 2006). In SPME, a polymer-coated fiber is extended into a headspace or liquid sample, and analytes are thermally desorbed in a gas chromatograph injection port. Recently, Loughrin (2006) compared stir bar sorbtive extraction (SBSE) with SPME for the quantification of malodors in wastewater. Stir bar sorbtive extraction is similar to SPME except that a polymer coating (polydimethylsiloxane) is placed over a glass-coated magnetic stir bar. Compared with SPME, SBSE had comparable accuracy and greater precision for quantifying aromatic malodorous compounds in wastewater. Later, an equilibrium sampler was developed using SBSE for the quantification of these malodorous compounds in wastewater in situ (Loughrin and Way, 2006). Using these samplers, it was possible to quantify malodorous compounds in a swine waste lagoon.

In this study, we measured the concentrations of malodorous compounds in a swine waste lagoon from the late summer to late fall of 2006 while monitoring weather conditions and the solids, $\mathrm{pH}$, carbon, and nitrogen $(\mathrm{N})$ content of the wastewater. By doing this, we were able to note seasonal changes in the concentrations of malodorous compounds and note the weather conditions and management practices, such as field application of wastewater, that might have affected the concentrations of the malodorous compounds.

\section{Materials and Methods}

\section{Measurement of Odor Compounds}

Odor compounds in the lagoon were measured as described previously (Loughrin and Way, 2006). Briefly, waterproof submersible magnetic stir plates were suspended in the lagoon by the means of threaded steel rods attached to floats. Initially, the stir plates were suspended at depths of 10,50 , and $100 \mathrm{~cm}$ and later at depths of 10,100, and $170 \mathrm{~cm}$ during the late summer to early fall of 2006 until the lagoon was pumped down during field application of wastewater. Thereafter, water samples were taken at depths of $10 \mathrm{~cm}$. Odor compounds were absorbed onto preconditioned Twister stir bars (Gerstel USA, Baltimore $\mathrm{MD}$ ) for $3 \mathrm{~h}$, after which the stir bars were placed in autosampler vials and stored at $4^{\circ} \mathrm{C}$ until analyzed as described below.

Manure was collected underneath slatted flooring in each swine house and gravity drained into the lagoon weekly by removal of a drain plug. Odor compounds in the flushed manure were measured by collecting samples from the outlet end of the pipes and extraction of 40-mL samples of the flush water in the laboratory with preconditioned Twisters as described below.

\section{Gas Chromatography-Mass Spectroscopy}

Twister stir bars were desorbed in a Gerstel Model TDSA desorption unit interfaced to a Varian model 3800 gas chromato- graph and Varian Star mass spectrometer (Varian Associates, Palo Alto, CA). After an initial time of $0.25 \mathrm{~min}$ and an initial temperature of $25^{\circ} \mathrm{C}$, the thermal desorption unit was programmed to $225^{\circ} \mathrm{C}$ and held for $3 \mathrm{~min}$. Compounds were transferred at $240^{\circ} \mathrm{C}$ in splitless mode to a cooled injector maintained at $-55^{\circ} \mathrm{C}$ with liquid $\mathrm{CO}_{2}$ and transferred to a $30 \mathrm{~m}$ by $0.25 \mathrm{~mm}$ VF-23MS column with a film thickness of $0.25 \mu \mathrm{m}$ (Varian Associates) using a $20: 1$ split by heating the injector at $10^{\circ} \mathrm{C} \mathrm{s}^{-1}$ to $300^{\circ} \mathrm{C}$. This temperature was held for $3 \mathrm{~min}$.

Gas chromatography-mass spectroscopy was performed as follows: column oven $30^{\circ} \mathrm{C}$ for $1 \mathrm{~min}$, then programmed at $4^{\circ} \mathrm{C}$ $\mathrm{min}^{-1}$ to $220^{\circ} \mathrm{C}$ and then at $20^{\circ} \mathrm{C} \mathrm{m^{-1 }}$ to $225^{\circ} \mathrm{C}$ and held for $2 \mathrm{~min}$. The column flow rate was held constant at $1 \mathrm{~mL} \mathrm{~min}^{-}$ ${ }^{1}$ using high-purity helium carrier gas, and, after a delay of 5 min, the mass spectrometer was operated in electron impact mode with a scan time of $0.45 \mathrm{~s} \mathrm{scan}^{-1}$, an emission current of 10 Hamperes, and a mass range of 45 to $225 \mathrm{amu}$.

\section{Wastewater Quality Analyses}

Wastewater samples were collected at the lagoon surface and above the sludge layer on 31 August, 20 September, and 18 October in a 1.0-L polyethylene vessel. Lagoon depth above the sludge on these three dates was 4.0, 1.8, and $2.6 \mathrm{~m}$, respectively. All analyses were performed according to Standard Methods (APHA, 1998). Total suspended solids (TSS) and volatile suspended solids (VSS) were determined according to Standard Methods 2540 $\mathrm{D}$ and $2540 \mathrm{E}$, respectively. The TSS were that portion of solids retained on a glass microfiber filter with a nominal pore size of $1.5 \mu \mathrm{m}$ (Whatman grade 934-AH; Whatman, Clifton, NJ) after filtration and drying to constant weight at $105^{\circ} \mathrm{C}$, whereas VSS was that portion of TSS that was lost on ignition in a muffle furnace at $500^{\circ} \mathrm{C}$ for $15 \mathrm{~min}$. Total organic carbon (TOC) and $\mathrm{N}$ analyses were performed on an Elementar Vario Max carbon-nitrogen analyzer (Elementar USA, Mt. Laurel, NJ).

\section{Meteorological Data}

Data were collected using a 15-channel HOBO weather station (Onset Computer Corp., Bourne, MA) placed approximately $20 \mathrm{~m}$ from the southwest corner of the waste lagoon. Wind speed, direction, and gust speed were measured by a sensor mounted at a height of $3 \mathrm{~m}$ above the ground. Humidity and air temperature probes were placed in a solar radiation shield at a height of $2 \mathrm{~m}$, and rainfall was measured with a tipping-bucket rain gauge mounted at $3 \mathrm{~m}$. Solar radiation was measured with a silicon pyranometer with a spectral range of 300 to $1100 \mathrm{~nm}$ also mounted at $2 \mathrm{~m}$. Barometric pressure was monitored with a sensor mounted inside the case of the data logger. Wastewater temperatures were monitored with HOBO probes. One was floated on the surface of the lagoon, and the other was weighted with lead sinkers and sunk to the bottom of the lagoon. Both probes were moored to an anchor at the edge of the lagoon for retrieval.

In the case of all air measurements, data were collected at 5-s intervals and averaged over 5-min intervals, and water temperatures were recorded every $5 \mathrm{~min}$. 


\section{Results and Discussion}

When sampling was begun on the 8 August, we collected samples at three depths, starting at $10 \mathrm{~cm}$ and varying from 60 to $180 \mathrm{~cm}$. On 14 September, field application of wastewater was begun and continued intermittently over the next 2 wk. Before partial drainage, the lagoon averaged about $4 \mathrm{~m}$ in depth and was lowered to less than $1 \mathrm{~m}$ thereafter. From 6 October on, all samples were taken at a depth of $10 \mathrm{~cm}$ due to the low depth of the lagoon.

For samples taken before 14 September, there was a distinct tendency for malodorous compounds to occur in higher concentrations at the lagoon surface than at the middle or lower depths (Table 1). Concentrations of $p$-cresol, $m$-cresol, $p$-ethylphenol, and skatole were highest at the 10-cm sampling depth; concentrations of the latter three compounds were significantly higher. The concentrations of all compounds were lowest at the middle depth of the lagoon, except for $p$-cresol and indole, which showed no difference. It is possible that differences in concentrations with depth noted in the present study reflect a gradient that is caused by temperature stratification of the lagoon. Baehr and Zapecza (1998), for instance, found that vertical stratification of methyl tert-butyl ether (MTBE) occurred in lakes that had undergone temperature stratification in early summer. Therefore, insofar as MTBE is largely introduced into lakes at the surface by spills and the incomplete combustion of gasoline, in a body of water in which little or no vertical mixing of lake water occurs, MTBE concentrations decrease with depth. In the fall, as the lakes became vertically mixed, Baehr and Zapecza (1998) found that MTBE concentration gradients disappeared.

Methyl tert-butyl ether has a $\log _{10}$ octanol-water partition coefficient $\left(k_{o w}\right)$ of 0.94 and a boiling point of $55^{\circ} \mathrm{C}$ (National Library of Medicine, 2007), whereas the malodorous compounds of the present study have $\log _{10}$ $k_{\text {ow }}$ values ranging from 1.46 to 2.60 and boiling points ranging from 182 to $266^{\circ} \mathrm{C}$. Although MTBE is considerably more volatile than our study compounds, MTBE and the malodorous compounds are comparatively polar (as indicated by $k_{o w}$ values) and are therefore relatively water soluble. Skatole, the most nonpolar compound in this study, for instance, has a water solubility of $498 \mathrm{mg} \mathrm{L}^{-1}$ (National Library of Medicine, 2007).

In the present study, flush water entered the lagoon from pipes at the surface of the wastewater. It is therefore possible that in a manner similar to that for MTBE, the concentration of malodorous compounds was higher near the surface due to their being introduced at the top of the lagoon
Table 1. Malodorous compounds depth profile in lagoon from 9 Aug. through 14 Sept.†

\begin{tabular}{lccc} 
& \multicolumn{3}{c}{ Concentration } \\
\cline { 2 - 4 } Compound & Upper & Mepth \\
\cline { 2 - 4 } & \multicolumn{3}{c}{ Middle } \\
\cline { 2 - 4 } Phenol & $2.6 \pm 0.8 \mathrm{a} \mathrm{L}^{-1}$ & $2.6 \pm 0.9 \mathrm{a}$ & $5.1 \pm 2.5 \mathrm{a}$ \\
$p$-Cresol & $42.1 \pm 18.0 \mathrm{a}$ & $34.5 \pm 15.8 \mathrm{a}$ & $34.6 \pm 15.8 \mathrm{a}$ \\
$m$-Cresol & $14.0 \pm 15.8 \mathrm{a}$ & $8.2 \pm 3.0 \mathrm{ab}$ & $4.8 \pm 2.7 \mathrm{~b}$ \\
$p$-Ethylphenol & $48.7 \pm 17.2 \mathrm{a}$ & $30.2 \pm 11.9 \mathrm{~b}$ & $35.7 \pm 13.1 \mathrm{ab}$ \\
Indole & $0.8 \pm 0.1 \mathrm{a}$ & $0.8 \pm 0.1 \mathrm{a}$ & $0.9 \pm 0.3 \mathrm{a}$ \\
Skatole & $54.4 \pm 14.3 \mathrm{a}$ & $23.6 \pm 6.6 \mathrm{~b}$ & $38.0 \pm 13.7 \mathrm{ab}$ \\
\hline
\end{tabular}

† Data represent the mean \pm SE of five sampling dates from 8 Aug. through 14 Sept. 2006. Means followed by the same letter are not significantly different at $p=0.05$ by a Duncan's multiple range test.

and temperature stratification of the wastewater, which prevented vertical mixing.

On bright sunny days, temperatures at the surface of the lagoon were notably higher than air temperatures or wastewater temperatures near the bottom of the lagoon, whereas on cloudier days, air temperatures were higher than those of the lagoon surface (Fig. 1). The dark coloration of the lagoon surface was responsible for the high daytime temperature of the lagoon surface on these days just as the high heat capacity of the water would be responsible for the relatively warm surface overnight lows. It is conceivable that temperature stratification of the lagoon was responsible for the differences seen in the concentrations of malodorous compounds at different depths.

During the previous winter, we sampled another waste lagoon on the same property and found concentrations of malodorous compounds that averaged 3- to 200-fold higher than those presented in Table 1 (Loughrin and Way, 2006). Al-

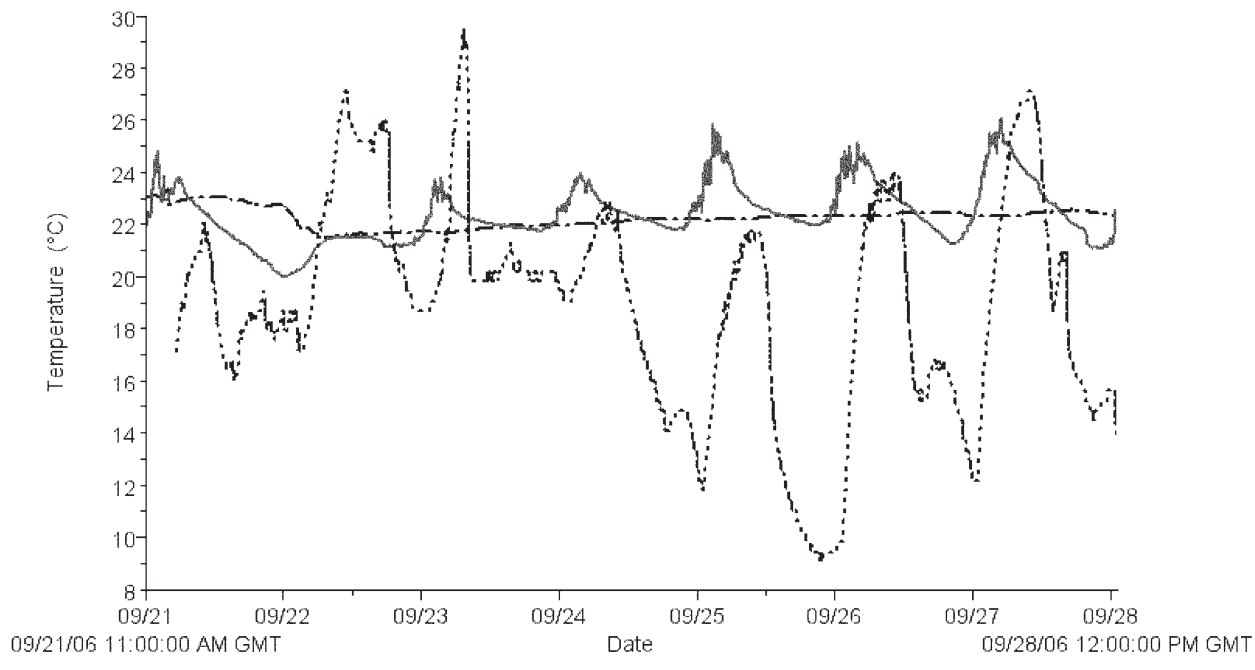

Air Temperature Water Surface Temperature -.......... Sludge Temperature

Fig. 1. Temperatures in the air, at the lagoon surface, and in the lagoon sludge during a 1-wk period. 


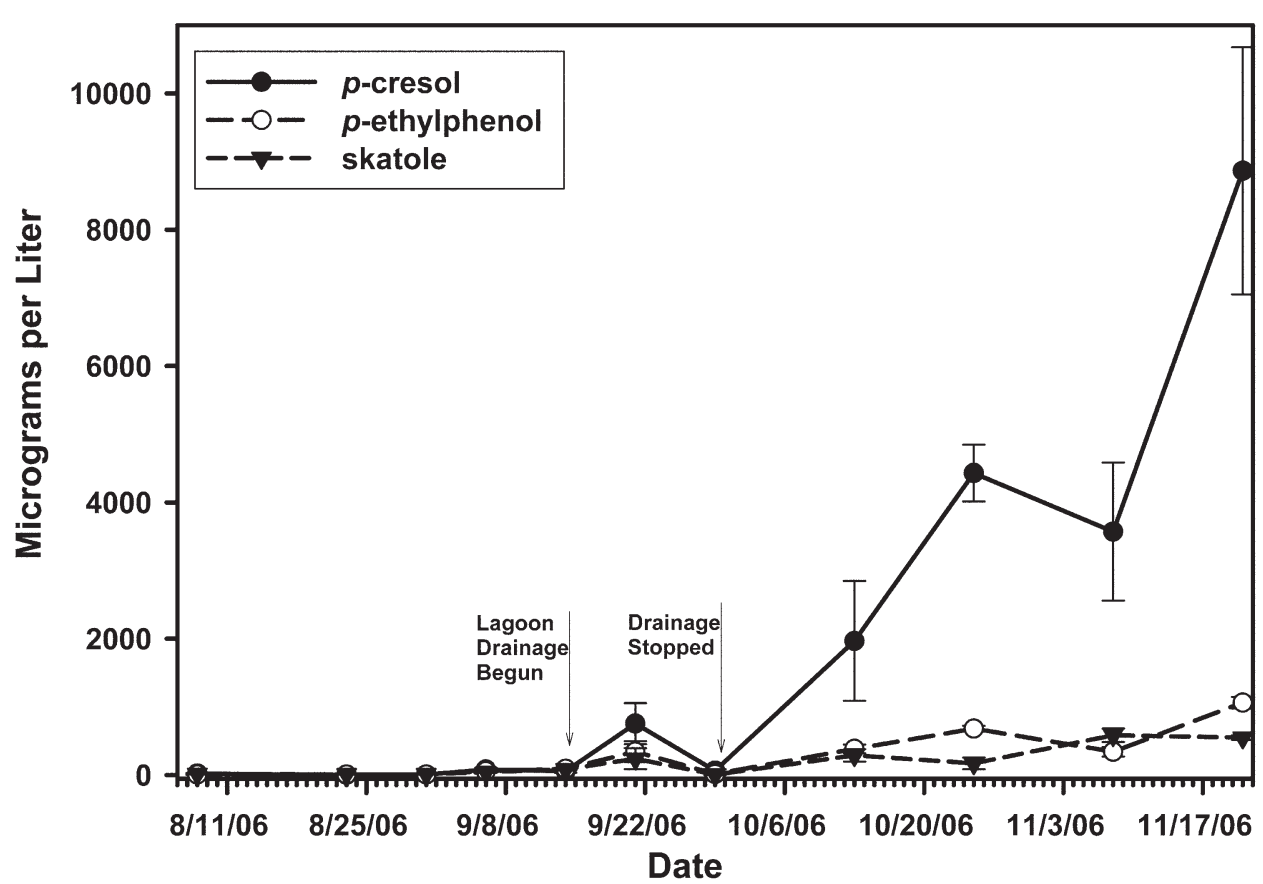

Fig. 2. Concentration of skatole, $p$-cresol, and $p$-ethylphenol in swine waste lagoon from late August to mid-November 2006.

though this lagoon was much smaller than the lagoon sampled here and received proportionally more waste, we feel that the higher concentrations found in the other lagoon largely reflect a seasonal difference in the concentration of malodorous compounds rather than a difference in management practice.

When the data on the concentrations of the three main malodorous compounds were pooled for all depths, the trend was for their concentrations to slowly increase from 31 August until 14 September (Fig. 2). On 14 September, the lagoon was partially emptied over a period of approximately $2 \mathrm{wk}$ and, when sampled on 21 September, the concentrations of these compounds had increased by about fourfold (from approximately $300 \mu \mathrm{g} \mathrm{L}^{-1}$ to about $1200 \mu \mathrm{g} \mathrm{L}^{-1}$ ). On 29 September, their concentrations had returned to concentrations comparable to that found at the beginning of the application period, increased when sampled again on 13 October, and continued to increase through the fall season. Additional changes were noted in other wastewater quality parameters during this same period. The $\mathrm{pH}$ of the lagoon had dropped from approximately 8.0 to 7.2 during lagoon pumping (Table 2), whereas TSS, VSS, TOC, and N content increased during this period and remained elevated thereafter.

It seems certain that the marked rises in malodor concentrations that occurred on 21 September and on 13 October were a direct result of lowering of the lagoon that occurred intermittently over the 2 -wk span. It is possible that, by removing a large portion of the lagoon's volume, freshly discharged waste entering into the lagoon accounted for a higher percentage of the total volume, which was then reflected in the relatively high concentration of malodorous compounds. Support for this deduction is given by the relatively high concentration of malodorous compounds and other organic matter in raw flushed manure (Table 3). Metacresol and $p$-cresol were not separated on the VF-23MS column at these high concentrations and so are reported as a single peak. It is also possible that agitation of the sludge during the lagoon pumping served to increase concentrations of malodorous compounds. We feel that the increases in TSS, VSS, N, and TOC seen at the bottom of the lagoon during this period are probably related to the agitation of the sludge layer that occurred during pumping of the lagoon.

The decline in the concentrations of malodorous compounds seen on 29 September could be due to further pumping of the lagoon that occurred between then and 14 September and the removal of the recently added waste. When sampling was conducted on 21 September and 13 October, large volumes of wastes were being discharged into the lagoon over a period of at least several hours. This probably contributed to the relatively high concentrations of malodorous compounds seen on these dates as opposed to the previous sampling dates of 14 and 29 September.

Although both of the marked increases in the concentrations of malodorous compounds (i.e., on the 21 September and 13 October) seem to be due to the partial emptying of the lagoon, the overall trend for the concentrations of malodors to increase after pumping down of the lagoon also seems likely to be related directly or indirectly to declining temperatures. In early August, when chemical analyses were begun, daily air temperature highs were in the mid-thirties, and lows were in the upper twenties. By mid-November, when the last collection was performed, daily highs were variable, ranging from about 20 to about $10^{\circ} \mathrm{C}$, and
Table 2. Liquid analyses performed on the samples collected at lagoon surface and above sludge layer. $\dagger$

\begin{tabular}{|c|c|c|c|c|c|c|c|c|c|c|}
\hline \multirow[b]{2}{*}{ Date } & \multicolumn{2}{|c|}{$\mathrm{pH}$} & \multicolumn{2}{|c|}{ TSS‡ } & \multicolumn{2}{|c|}{ VSS } & \multicolumn{2}{|c|}{ Total N } & \multicolumn{2}{|c|}{ TOC } \\
\hline & Top & Bottom & Top & Bottom & Top & Bottom & Top & Bottom & Top & Bottom \\
\hline & & & & & & $\lg \mathrm{L}^{-1}$ & & & & \\
\hline 21 Aug. & 7.96 & 7.89 & 1850 & 9080 & 850 & 5000 & 610 & 800 & 1100 & 3600 \\
\hline 20 Sept. & 7.96 & 7.22 & 4320 & 24,500 & 1700 & 7100 & 637 & 4130 & 1185 & 22,300 \\
\hline 18 Oct. & 8.03 & 7.55 & 1630 & 32,100 & 13,100 & 13,100 & 765 & 3820 & 1850 & 19,300 \\
\hline
\end{tabular}

† Data represent the mean of three determinations.

‡TOC, total organic carbon; TSS, total suspended solids; VSS, volatile suspended solids. lows ranged from about 15 to near $-5^{\circ} \mathrm{C}$. Lagoon surface highs generally approximated air temperature highs except that they were higher on bright sunny days, lower on cloudy days, and, due to water's high heat capacity, overnight lows were considerably warmer than were overnight air temperatures 
(Fig. 1). Sludge temperatures, on the other hand, were not variable and declined slowly, lagging a number of days behind those of the average air temperature. In early August, sludge temperatures were nearly constant at slightly above $30^{\circ} \mathrm{C}$, had dropped only $5^{\circ} \mathrm{C}$ in 1 mo, and had dropped only about $15^{\circ} \mathrm{C}$ during the 3.5 mo, during which we performed our measurements. Figure 3 shows air and sludge temperatures averaged over 24-h periods from early September through mid-November 2006.

It is likely that slowly declining temperatures were at least in part responsible for the slight rise in the concentrations of malodorous compounds that was seen before partial pumping down of the lagoon. From 31 August to 14 September, lagoon sludge temperatures had declined from 27.7 to $23.9^{\circ} \mathrm{C}$, whereas total measured malodors had increased from approximately $30 \mu \mathrm{g} \mathrm{L}^{-1}$ to approximately $330 \mu \mathrm{g} \mathrm{L}^{-1}$. It is likely that cooler weather retards evaporation of volatile compounds from the lagoon and allows for their accumulation. The large increases seen on 14 September and especially on 29 September seem to be a direct consequence of the lowering of the lagoon. We estimate that the volume of the lagoon was lowered about fivefold during field application: A large part of the solids remaining afterward consisted of recently added manure, which had very high concentrations of malodorous compounds (Table 3). Concentrations of malodors increased about fourfold from 14 September to 21 September and 16-fold by 25 October. After lagoon pumping, the continually dropping temperatures could have retarded evaporation of malodors from the lagoon and allowed for their accumulation to a degree not seen during warmer weather. However, sludge temperatures had only declined to $14.8^{\circ} \mathrm{C}$ by 25 October. This relatively modest temperature decline would seem to be insufficient for the large increase in the concentrations of malodors. It is likely that a seasonal decline, related to shorter days or falling temperatures, in the populations of organisms such as photosynthetic bacteria (Wenke and Vogt, 1981) and/or methanogenic consortia (Wang et al., 1988; Gu and Berry, 1991) were at least partially responsible for increases in the concentrations of malodors.

Do et al. (2003), for instance, found that the population of photosynthetic purple nonsulfur bacteria peaked in the late summer to early fall and that Rhodobacter sp. strain PS9 was capable of growth on phenol, $p$-cresol, and skatole. Gu and Berry (1991) found that a methanogenic consortium from sewage sludge was capable of degrading indole, and DeSutter and Ham (2005) found that methane production from a swine waste lagoon in Kansas varied greatly during the year, peaking in June. Perhaps the accumulation of solids, $\mathrm{N}$, and TOC that we noted after partial pumpdown of the lagoon (Table 2) is due to a seasonal decline in the population of catabolic organisms in the lagoon and a consequential inability to effectively degrade the recently added wastes.
Table 3. Selected characteristics of raw flushed manure.

\begin{tabular}{|c|c|}
\hline Parameter & Concentrationt \\
\hline & $\mu g L^{-1}$ \\
\hline Phenol & $7780 \pm 1345$ \\
\hline$p$-Cresol + m-Cresol & $57,600 \pm 6870$ \\
\hline$p$-Ethylphenol & $6060 \pm 702$ \\
\hline Indole & $1100 \pm 331$ \\
\hline \multirow[t]{2}{*}{ Skatole } & $2750 \pm 369$ \\
\hline & $\mathrm{mg} \mathrm{L}^{-1}$ \\
\hline TSS $\neq$ & $24,400 \pm 6400$ \\
\hline VSS & $6020 \pm 1670$ \\
\hline Total N & $3180 \pm 911$ \\
\hline Total organic carbon & $11,560 \pm 6690$ \\
\hline
\end{tabular}

On the other hand, after field application of lagoon wastewater, the lagoon surface was considerably lower and consequently seemed to receive less wind. Bajwa et al. (2006) found that wind is an important factor driving volatilization of ammonia from anaerobic waste lagoons. It seems likely that, as for ammonia, volatilization of odor compounds should also be influenced by wind.

More research needs to be conducted to establish the relative importance of physical and biotic factors in controlling malodor concentrations in anaerobic lagoons. Regardless of the cause, when we stopped sampling, the concentrations of malodorous compounds in the lagoon were over 100 -fold higher than when sampling was begun in early August (Table 4).

Malodors emitted from CAFOs are complex mixtures of compounds, and there is considerable difference in opinion as to the compounds that are important contributors to swine waste malodor (Spoelstra, 1980; Williams, 1984; Mackie et al., 1998; Zhu et al., 1999; Schiffman et al., 2001; Zahn et al., 2001; McGinn et al., 2003). In this study, we used SBSE to measure a selected subset of malodorous compounds from a lagoon in situ. Other compounds, such as volatile fatty acids (VFA) (Yo, 1999; Zahn et al., 2001) and sulfides (Yasuhara, 1980), are thought to be important components of swine waste malodor. However, at

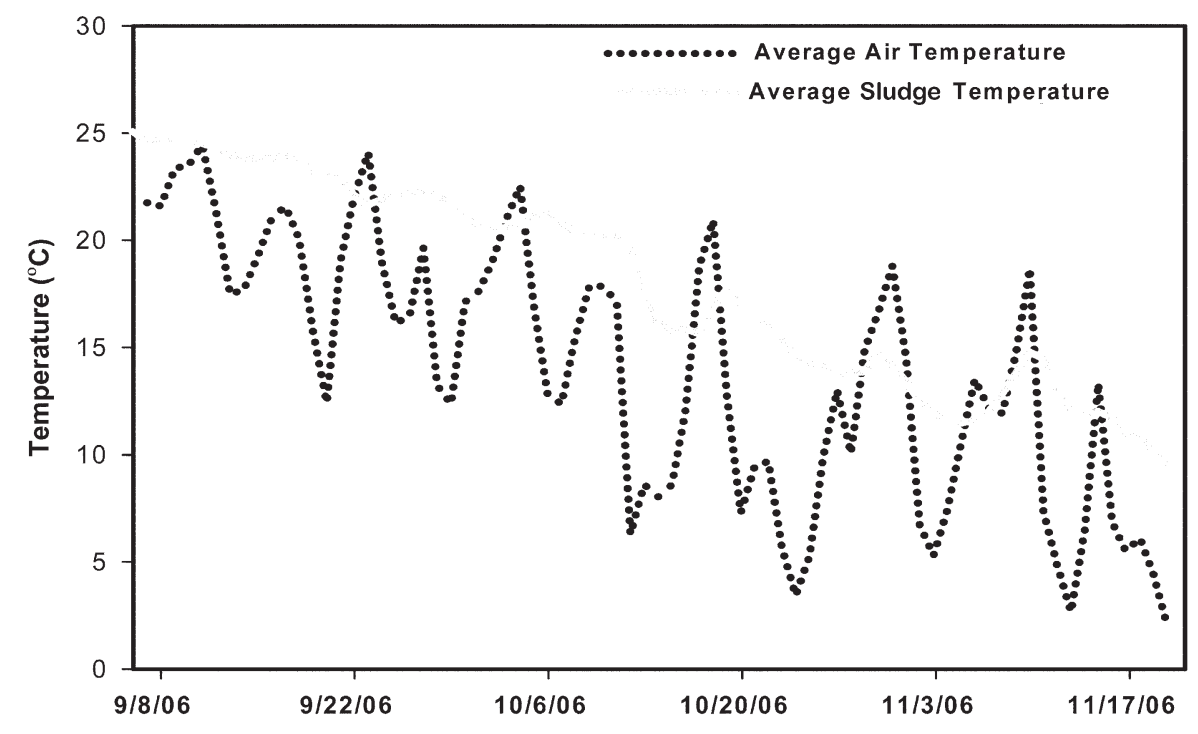

Fig. 3. Average daily air and sludge temperatures from early September to late November 2006. 
Table 4. Concentrations of volatile compounds measured in the swine waste lagoon in early August and mid-November 2006.†

\begin{tabular}{|c|c|c|}
\hline \multirow[b]{2}{*}{ Compound } & \multicolumn{2}{|c|}{ Concentration } \\
\hline & 8 Aug. & 21 Nov. \\
\hline & \multicolumn{2}{|c|}{$-\mu g L^{-1}$} \\
\hline Phenol & $2.0 \pm 0.2$ & $330 \pm 113$ \\
\hline$p$-Cresol & $23.8 \pm 8.5$ & $8870 \pm 1810$ \\
\hline$m$-Cresol & $4.3 \pm 1.9$ & $-\ddagger$ \\
\hline$p$-Ethylphenol & $8.0 \pm 2.3$ & $1060 \pm 86.4$ \\
\hline Indole & $0.7 \pm 0.3$ & $76.8 \pm 10.2$ \\
\hline Skatole & $16.8 \pm 5.5$ & $551 \pm 33.0$ \\
\hline
\end{tabular}

† Data represent the mean $\pm \mathrm{SE}$ of six determinations.

₹ Compound not separated from $p$-cresol.

the high $\mathrm{pH}$ of this waste lagoon (about 8.3), VFA and sulfide exist in their ionized forms and are not amenable to this technique, with the exception that, in the relatively high concentrations of malodors found in anaerobic pits, VFA may be measured using Twister stir bars (Loughrin, 2006). In any case, the aromatic amino acids are ideal candidates for monitoring malodorous plumes from CAFOs. Because they are relatively unreactive, they are likely to persist in the air longer than are sulfides and VFA. This makes their measurement less problematic. Their relatively low concentrations (Schiffman et al., 2001), however, make measurement of these compounds at any distance from an odor source challenging. In the future, we need to develop sensitive air monitoring methods for the measurement of these compounds from swine waste lagoons.

\section{Conclusions}

We found that the equilibrium samplers may be used to monitor malodorous compounds in a swine waste lagoon and track changes in their concentrations due to season, management practice, and depth. Given the large changes in the concentration of malodors that occurred within a relatively short period, no meaningful study of malodor fluxes can be done without concomitant measurements of the source of these emissions. These samplers, used in conjunction with air monitoring methods, should allow us to better evaluate the environmental factors influencing the emission of malodors from waste lagoons.

\section{Acknowledgments}

We thank Joe St. Claire, Stacy Antle, and Michelle Reliford for technical assistance. This research was part of USDA-ARS National Program 206: Manure and By-product Utilization and was funded by USDA grant 58-6445-6-068. Mention of a trademark or product anywhere in this article is to describe experimental procedures and does not constitute a guarantee or warranty of the product by the USDA and does not imply its approval to the exclusion of other products or vendors that may also be suitable.

\section{References}

APHA. 1998. Standard methods for the examination of water and wastewater. Am. Public Health Assoc., Washington, DC.

Bajwa, K.S., V.P. Aneja, and S.P. Arya. 2006. Measurement and estimation of ammonia emissions from lagoon-atmosphere interface using a coupled mass transfer and chemical reactions model, and an equilibrium model. Atmos. Environ. 40(suppl.):275-286.
Baehr, A.L., and O.S. Zapecza. 1998. Methyl tert-butyl ether (MTBE) and other volatile organic compounds in lakes in Byram township, Sussex County, New Jersey, summer 1998. USGS Investigations Rep. 984264, 8 pp. USGS, Washington, DC.

Buchholz, K.D., and J. Pawliszyn. 1994. Optimization of solid-phase microextraction conditions for determination of phenols. Anal. Chem. 66:160-167.

DeSutter, T.M., and J.M. Ham. 2005. Lagoon-biogas emissions and carbon balance estimates of a swine production facility. J. Environ. Qual. 34:198-206.

Do, Y.S., T.M. Schmidt, J.A. Zahn, E.S. Boyd, A. de la Mora, and A.A. DiSpirito. 2003. Role of Rhodobacter sp. strain PS9, a purple nonsulfur photosynthetic bacterium isolated from an anaerobic swine waste lagoon, in odor remediation. Appl. Environ. Microbiol. 69:1710-1720.

Elsden, S.R., M.G. Hilton, and J.M. Walker. 1976. The end products of the metabolism of aromatic amino acids by Clostridia. Arch. Microbiol. 107:283-288.

Gralapp, A.K., W.J. Powesand, and D.S. Bundy. 2001. Comparison of olfactometry, gas chromatography, and electronic nose technology for measurement of indoor air from swine facilities. Trans. ASAE 44:1283-1290.

Gu, J.-D., and D.F. Berry. 1991. Degradation of substituted indoles by an indole-degrading methanogenic consortium. Appl. Environ. Microbiol. 57:2622-2627.

Hobbs, P.J., T.H. Nisselbrook, and B.F. Pain. 1995. Assessment of odours from livestock wastes by a photoionization detector, an electronic nose, olfactometry, and gas chromatography-mass spectroscopy. J. Agric. Eng. Res. 60:137-144.

Loughrin, J.H. 2006. A comparison of solid phase microextraction and stir bar sorbtive extraction for the quantification of malodors in wastewater. J. Agric. Food Chem. 54:3237-3241.

Loughrin, J.H., and T.R. Way. 2006. An equilibrium sampler for malodors in wastewater. Trans. ASABE 49:1167-1175.

Mackie, R.I., P.G. Stroot, and V.H. Varel. 1998. Biochemical identification and biological origin of key odor components in livestock waste. J. Anim. Sci. 76:1331-1342.

McGinn, S.N., H.H. Janzen, and T. Coates. 2003. Atmospheric ammonia, volatile fatty acids, and other odorants near beef feedlots. J. Environ. Qual. 32:1173-1182.

National Library of Medicine. 2007. ChemIDplus Advanced. Bethesda, Md.: U.S. National Library of Medicine. Available at http://chem.sis.nlm. nih.gov/chemidplus/ (verified 25 July 2007).

Schiffman, S.S., J.L. Jeanette, and J.H. Raymer. 2001. Quantification of odors and odorants from swine operations in North Carolina. Agric. For. Meteorol. 108:213-240.

Spoelstra, S.K. 1977. Simple phenols and indoles in anaerobically stored piggery wastes. J. Sci. Food Agric. 28:415-423.

Spoelstra, S.K. 1980. Origin of objectionable odorous components in piggery wastes and the possibility of applying indicator components for studying odour development. Agric. Environ. 5:241-260.

van Beek, S., and F.G. Priest. 2000. Decarboxylation of substituted cinnamic acids by lactic acid bacteria isolated during malt whisky fermentation. Appl. Environ. Microbiol. 66:5322-5328.

Wang, Y.-T., M.T. Suidan, J.T. Pfeffer, and I. Najm. 1988. Effects of some alkyl phenols on methanogenic degradation of phenol. Appl. Environ. Microbiol. 54:1277-1279.

Wenke, T.L., and J.C. Vogt. 1981. Temporal changes in a pink feedlot lagoon. Appl. Environ. Microbiol. 41:381-385.

Williams, A.G. 1984. Indicators of piggery slurry odour offensiveness. Agric. Wastes 10:15-36.

Yasuhara, A. 1980. Relationship between odor and odorous components in solid swine manure. Chemosphere 9:587-592.

Yo, S.-P. 1999. Analysis of volatile fatty acids in wastewater collected from a pig farm by a solid phase microextraction method. Chemosphere 38:823-834.

Zahn, J.A., A.A. DiSpirito, Y.S. Do, B.E. Brooks, E.E. Cooper, and J.L. Hatfield. 2001. Correlation of human olfactory responses to airborne concentrations of malodorous volatile organic compounds emitted from swine effluent. J. Environ. Qual. 30:624-634.

Zahn, J.A., J.L. Hatfield, Y.S. Do, A.A. Dispirito, D.A. Laird, and R.L. Pfeiffer. 1997. Characterization of volatile organic emissions and wastes from a swine production facility. J. Environ. Qual. 26:1687-1696.

Zhu, J., G.L. Riskowski, and M. Torremorell. 1999. Volatile fatty acids as odor indicators in swine manure—a critical review. Trans. ASAE 42:175-182. 